\title{
Methanobacterium arcticum sp. nov., a methanogenic archaeon from Holocene Arctic permafrost
}

\author{
Viktoria Shcherbakova, ${ }^{1}$ Elizaveta Rivkina, ${ }^{2}$ Svetlana Pecheritsyna, ${ }^{1}$ \\ Kestus Laurinavichius, ${ }^{1}$ Nataliya Suzina ${ }^{1}$ and David Gilichinsky ${ }^{2}$ \\ ${ }^{1}$ Skryabin Institute of Biochemistry and Physiology of Microorganisms, Russian Academy of \\ Sciences, 142290, Pushchino, Moscow Region, Russian Federation \\ ${ }^{2}$ Institute of Physicochemical and Biological Problems in Soil Sciences, Russian Academy of \\ Sciences, 142290, Pushchino, Moscow Region, Russian Federation
}

Correspondence

Viktoria Shcherbakova

shcherb@ibpm.pushchino.ru

\begin{abstract}
A mesophilic, non-motile, hydrogenotrophic, rod-shaped methanogen, designated $\mathrm{M} 2^{\top}$, was isolated from Holocene permafrost sediments of the Kolyma lowland in the Russian Arctic. Cells were 3-6 $\mu \mathrm{m}$ long and 0.45-0.5 $\mu \mathrm{m}$ wide. Strain $\mathrm{M} 2^{\top}$ grew on $\mathrm{H}_{2} / \mathrm{CO}_{2}$ and formate. Optimum conditions for growth were $37^{\circ} \mathrm{C}, \mathrm{pH}$ 6.8-7.2 and $0.1 \mathrm{M} \mathrm{NaCl}$. The DNA G +C content was $38.1 \mathrm{~mol} \%$. On the basis of $16 \mathrm{~S}$ rRNA gene sequence comparison with known methanogens, strain $\mathrm{M} 2^{\top}$ was affiliated with the genus Methanobacterium and was most closely related to Methanobacterium veterum MK4 ${ }^{\top}$ and Methanobacterium bryantii DSM $863^{\top}$ (both $99 \% 16 \mathrm{~S}$ rRNA gene sequence similarity). However, no significant DNA-DNA relatedness was observed between strain $M 2^{\top}$ and these type strains. We propose that strain $\mathrm{M}^{\top}$ represents a novel species, with the name Methanobacterium arcticum sp. nov., with type strain $\mathrm{M}^{\top}{ }^{\top}$ (=DSM $19844^{\top}=$ VKM B-2371 ${ }^{\top}$ ).
\end{abstract}

At the time of writing, the genus Methanobacterium comprises 24 species with validly published names, although a number of them have been reclassified (http://www. bacterio.cict.fr/m/methanobacterium.html). The remaining members of the genus are hydrogenotrophic mesophiles, and only Methanobacterium subterraneum (Kotelnikova et al., 1998) and Methanobacterium aarhusense (Shlimon et al., 2004) were isolated from permanently cold habitats.

One of the reasons for the presence of methane in permafrost is methane formation in sediments at above-zero temperatures followed by its conservation during freezing. At the same time, one cannot exclude the possibility of methane formation in permafrost at sub-zero temperatures. Previously, we isolated three strains of methanogenic archaea from samples of Pliocene and Holocene permafrost from Eastern Siberia (Rivkina et al., 2007). Strains $\mathrm{M}^{\mathrm{T}}$, MK3 and $\mathrm{MK} 4^{\mathrm{T}}$ were non-motile hydrogenotrophic rods. Strain $\mathrm{MK} 4^{\mathrm{T}}$ has been assigned to a novel species, Methanobacterium veterum (Krivushin et al., 2010). In the present study, we report the characterization of strain $\mathrm{M} 2^{\mathrm{T}}$.

Strain $\mathrm{M} 2^{\mathrm{T}}$ was isolated from a sample of deep $(2.0 \mathrm{~m})$ Holocene permafrost sediments of the Kolyma lowland,

The GenBank/EMBL/DDBJ accession number for the $16 \mathrm{~S}$ rRNA gene sequence of strain $\mathrm{M}^{\top}{ }^{\top}$ is DO517520.

A supplementary figure is available with the online version of this paper.
Russia $\left(70^{\circ} 06^{\prime} \mathrm{N} 154^{\circ} 04^{\prime} \mathrm{E}\right)$, by long-term enrichment (Rivkina et al., 2007). The protocols for drilling and subsequent handling of cores ensured that the retrieved material remained uncontaminated (Shi et al., 1997). Purity of the culture of strain $\mathrm{M} 2^{\mathrm{T}}$ was confirmed using the chromosomal DNA restriction pattern. The polyphasic characterization used the minimal standards detailed by Boone \& Whitman (1988). M. veterum $\mathrm{MK}^{\mathrm{T}}$ and Methanobacterium bryantii VKM B-1629 $9^{\mathrm{T}}$ were used as reference strains.

Gram-staining was performed following standard protocols (Smibert \& Krieg, 1994) and cells of strain $\mathrm{M} 2^{\mathrm{T}}$ stained Gram-negative. Cell morphology was examined using phase-contrast microscopy (I-2; Lumam) at $\times 1350$ magnification and electron microscopy (JEM-100; JEOL) with ultrathin sections as described previously (Shcherbakova et al., 2005). Cells of strain $\mathrm{M}^{\mathrm{T}}$ were non-motile, slightly curved rods (Fig. 1a), 0.45-0.50 $\mu \mathrm{m}$ wide and 3.0-6.0 $\mu \mathrm{m}$ long, often forming chains and filaments more than $30 \mu \mathrm{m}$ long. Cells of strain $\mathrm{M} 2{ }^{\mathrm{T}}$ divided by the formation of septa and exponentially growing cells were resistant to lysis by hypotonic solution (1\% SDS in distilled water). During stationary growth or long-term storage, strain $\mathrm{M} 2^{\mathrm{T}}$ formed cyst-like coccoid cells (Fig. 1b), in which the cytoplasm was more dense and differentiated surface layers were observed. The cell wall was $10-11 \mathrm{~nm}$ thick in vegetative cells and $50 \mathrm{~nm}$ thick in cyst-like cells. The formation of cyst-like 


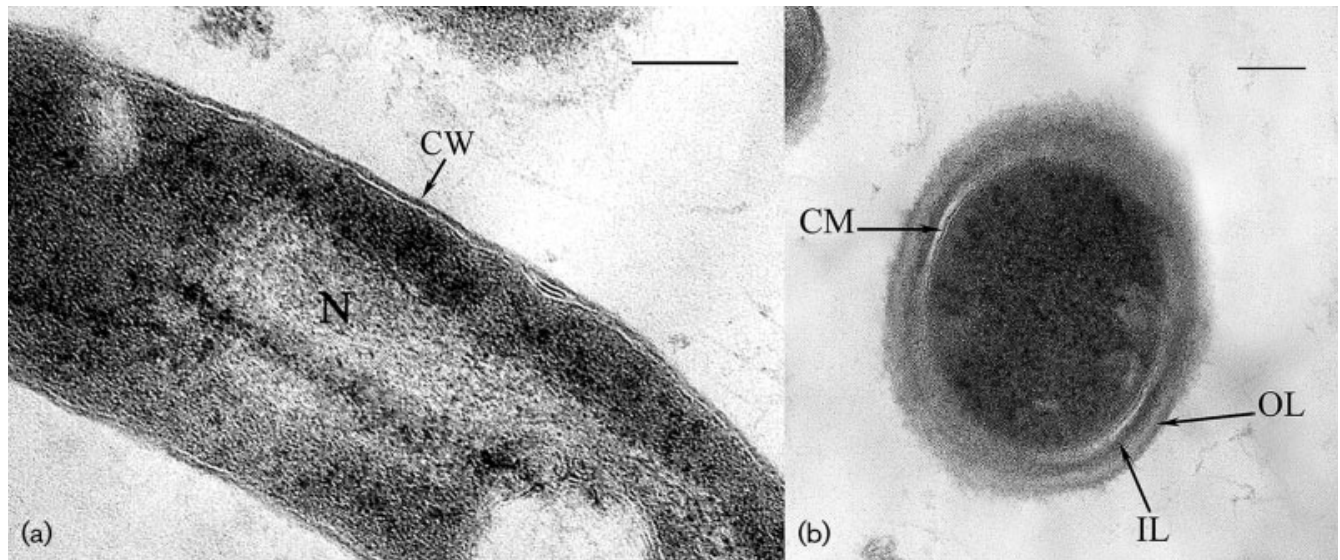

Fig. 1. Thin sections of cells of strain $M 2^{\top}$ showing a rod-shaped cell (a) and a cyst-like cell (b). CM, Cytoplasmic membrane; $\mathrm{CW}$, cell wall; IL, inner layer of cell wall; N, nucleoid; OL, outer layer of cell wall. Bars, $100 \mathrm{~nm}$.

cells in halophilic archaea has been shown during nutrient limitation (El'-Registan et al., 2006; Suzina et al., 2006). Subsequent investigation is needed to understand the conditions under which strain $\mathrm{M} 2^{\mathrm{T}}$ forms cyst-like cells.

Conditions for growth for strain $\mathrm{M} 2^{\mathrm{T}}$ and M. bryantii VKM B- $1629^{\mathrm{T}}$ (temperature, $\mathrm{pH}, \mathrm{NaCl}$ concentration and substrates required for methanogenesis) were determined in $\mathrm{MB}$ medium [containing $\mathrm{l}^{-1}: 0.05 \mathrm{~g}$ sodium acetate trihydrate, $0.45 \mathrm{~g}\left(\mathrm{NH}_{4}\right)_{2} \mathrm{SO}_{4}, 0.29 \mathrm{~g} \mathrm{~K}_{2} \mathrm{HPO}_{4}, 0.18 \mathrm{~g} \mathrm{KH}_{2} \mathrm{PO}_{4}, 0.12 \mathrm{~g}$ $\mathrm{MgSO}_{4} \cdot 7 \mathrm{H}_{2} \mathrm{O}, 0.06 \mathrm{~g} \mathrm{CaCl}_{2} .2 \mathrm{H}_{2} \mathrm{O}, 5.0 \mathrm{~g} \mathrm{NaCl}, 10 \mathrm{ml}$ vitamin solution (medium 141; DSMZ), $10 \mathrm{ml}$ trace element solution (medium 141; DSMZ), $0.001 \mathrm{~g}$ resazurin, $0.25 \mathrm{~g}$ cysteine hydrochloride hydrate, $0.25 \mathrm{~g} \mathrm{Na}_{2} \mathrm{~S} .9 \mathrm{H}_{2} \mathrm{O} ; \mathrm{H}_{2} / \mathrm{CO}_{2}$ $(80: 20)$ at $200 \mathrm{kPa}$; Balch et al., 1979; Sowers \& Noll, 1995] and for $M$. veterum $\mathrm{MK}^{\mathrm{T}}$ (temperature and substrates required for methanogenesis) in DSMZ medium 506 with the same modification (Krivushin et al., 2010). All tests were performed twice and confirmed by two transfers. Growth rate was estimated by measuring the concentration of methane in the gas phase (Powell, 1983). The effect of temperature on growth was tested at $-5,-2,5,10,15,24,28,37,45,50$ and $55{ }^{\circ} \mathrm{C}$, using a cryobath with ethylene glycol for the sub-zero temperatures. All strains were mesophiles (Morita, 1975): strain $\mathrm{M} 2{ }^{\mathrm{T}}$ grew at $15-45{ }^{\circ} \mathrm{C}$ (optimum $37{ }^{\circ} \mathrm{C}$ ), M. bryantii VKM B-1629 $9^{\mathrm{T}}$ grew at $20-50{ }^{\circ} \mathrm{C}$ (optimum $37{ }^{\circ} \mathrm{C}$ ) and $M$. veterum $\mathrm{MK}^{\mathrm{T}}$ grew at $10-50{ }^{\circ} \mathrm{C}$ (optimum $28^{\circ} \mathrm{C}$ ) (Supplementary Fig. S1, available in IJSEM Online). The $\mathrm{pH}$ of the basal medium was adjusted with sterile $1 \mathrm{M} \mathrm{HCl}$, $10 \%(\mathrm{w} / \mathrm{v}) \mathrm{NaHCO}_{3}$ or $8 \%(\mathrm{w} / \mathrm{v}) \mathrm{Na}_{2} \mathrm{CO}_{3}$. At the end of exponential growth, $\mathrm{pH}$ was decreased by no more than $0.2-$ $0.4 \mathrm{pH}$ units. Strain $\mathrm{M}^{\mathrm{T}}$ grew at $\mathrm{pH}$ 5.5-8.5 (optimum $\mathrm{pH}$ 6.8-7.2) and M. bryantii VKM B-1629 ${ }^{\mathrm{T}}$ grew at $\mathrm{pH} 5.8$ 8.8 (optimum $\mathrm{pH}$ 6.9-7.0). The effect of $\mathrm{NaCl}$ on growth was tested with $0,0.01,0.02,0.03,0.05,0.1,0.2,0.3,0.4$ and $0.5 \mathrm{M}$ $\mathrm{NaCl}$. Strain $\mathrm{M}^{\mathrm{T}}$ grew with $0-0.3 \mathrm{M} \mathrm{NaCl}$ (optimum $0.1 \mathrm{M}$ $\mathrm{NaCl}$ ). Growth of $M$. bryantii VKM B- $1629^{\mathrm{T}}$ was not affected by $\mathrm{NaCl}$ concentrations up to $0.3 \mathrm{M}$.
Growth with different carbon substrates was tested in the basal medium without sodium acetate as follows: $\mathrm{H}_{2} / \mathrm{CO}_{2}$, $20 \mathrm{mM}$ methanol, $50 \mathrm{mM}$ formate, $50 \mathrm{mM}$ acetate, $20 \mathrm{mM}$ ethanol, $20 \mathrm{mM}$ 2-propanol, $20 \mathrm{mM}$ 2-butanol, $50 \mathrm{mM}$ methanol $/ \mathrm{H}_{2}, 20 \mathrm{mM}$ methylamine $/ \mathrm{H}_{2}, 20 \mathrm{mM}$ methylamine and $20 \mathrm{mM}$ trimethylamine. Strain $\mathrm{M}^{\mathrm{T}}$ grew and produced methane with $\mathrm{H}_{2} / \mathrm{CO}_{2}\left(0.026 \mathrm{~h}^{-1}\right)$ and formate $\left(0.014 \mathrm{~h}^{-1}\right)$ and M. bryantii VKM B-1629 $9^{\mathrm{T}}$ grew with $\mathrm{H}_{2} / \mathrm{CO}_{2}\left(0.036 \mathrm{~h}^{-1}\right)$ and produced methane without visible growth with 2-propanol and 2-butanol. Growth of strain $\mathrm{M} 2{ }^{\mathrm{T}}$ was not stimulated by the addition of acetate ( 1 , $2,5,10,20 \mathrm{mM})$, yeast extract $\left(0.1\right.$ and $\left.0.5 \mathrm{~g} \mathrm{l}^{-1}\right)$, CoM $\left(25 \mathrm{mg} \mathrm{l}^{-1}\right)$ or Casamino acids $\left(1 \mathrm{~g} \mathrm{l}^{-1}\right)$. Growth of $M$. bryantii VKM B- $1629^{\mathrm{T}}$ was induced by the addition of acetate $(1-10 \mathrm{mM})$ and yeast extract $\left(0.1\right.$ and $\left.0.5 \mathrm{~g} \mathrm{l}^{-1}\right)$ and growth of $M$. veterum $\mathrm{MK} 4^{\mathrm{T}}$ was induced by addition of acetate (Krivushin et al., 2010).

The effect of antibiotics on strain $\mathrm{M} 2^{\mathrm{T}}$, M. veterum $\mathrm{MK} 4^{\mathrm{T}}$ and M. bryantii VKM B-1629 was determined by transferring 5-ml aliquots of culture to fresh medium containing $\left(\mathrm{l}^{-1}\right)$ chloramphenicol $(10 \mathrm{mg})$, bacitracin $(10 \mathrm{mg})$, polymyxin $(10 \mathrm{mg})$, vancomycin $(2000 \mathrm{mg})$, erythromycin $(1000 \mathrm{mg})$, kanamycin $(2000 \mathrm{mg})$ or penicillin G (2000 mg). Tests were performed in duplicate with a non-antibiotic control for 1 week at the optimum temperature. Strain $\mathrm{M}^{\mathrm{T}}$, M. veterum $\mathrm{MK} 4^{\mathrm{T}}$ and $M$. bryantii VKM B- $1629^{\mathrm{T}}$ were sensitive to chloramphenicol and polymyxin. Strain $\mathrm{M}^{\mathrm{T}}$ was slightly sensitive to penicillin and bacitracin but $M$. veterum $\mathrm{MK}^{\mathrm{T}}$ and $M$. bryantii VKM B-1629 ${ }^{\mathrm{T}}$ were sensitive to bacitracin and resistant to penicillin. Bacitracin inhibits the formation of lipid-bound murein precursors in members of the domain Bacteria (Whitman et al., 2006) and it may have the same effect on methanogens of the family Methanobacteriaceae in the domain Archaea, which have cell walls composed of pseudomurein (Konig, 1995). All strains were resistant to vancomycin, erythromycin and kanamycin. 


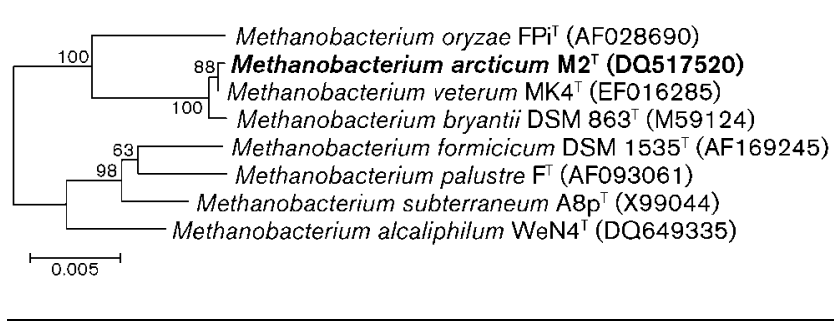

Fig. 2. Neighbour-joining phylogenetic tree based on $16 \mathrm{~S}$ rRNA gene sequences showing the position of strain $M 2^{\top}$ within the genus Methanobacterium. Bootstrap values $(>50 \%)$ based on 1000 replicates are shown at nodes. Bar, 5 substitutions per 1000 nucleotide positions.

Isolation of genomic DNA was carried out according to Marmur (1961). DNA-DNA hybridizations (four replicates) were performed as described by De Ley et al. (1970) and modified by Huß et al. (1983), using a Pye Unicam SP 1800 spectrophotometer equipped with a thermoprogrammer and hermetically sealed thermocuvettes. Standard deviations of hybridization experiments were between 5.0 and $10.5 \%$. DNA-DNA relatedness was 37 and $40 \%$ between strain $\mathrm{M} 2^{\mathrm{T}}$ and $M$. bryantii VKM B- $1629^{\mathrm{T}}$ and $M$. veterum $\mathrm{MK} 4^{\mathrm{T}}$, respectively, and $62 \%$ between M. bryantii VKM B $-1629^{\mathrm{T}}$ and $M$. veterum $\mathrm{MK} 4^{\mathrm{T}}$. The DNA G+C contents of strain $\mathrm{M} 2^{\mathrm{T}}, M$. bryantii VKM B- $1629^{\mathrm{T}}$ and $M$. veterum $\mathrm{MK}^{\mathrm{T}}$ were $38.1 \pm 0.3,35.2 \pm 0.5$ and $33.8 \pm$ $0.3 \mathrm{~mol} \%$, respectively, which were within the limits defined for the genus Methanobacterium.

For amplification and sequencing of the 16S rRNA gene, DNA was extracted using the method described by
Sambrook et al. (1989) and the 16S rRNA gene was amplified by PCR using the archaeal $16 \mathrm{~S}$ rRNA gene primers 8F (5'-TCCGGTTGATCCTGCCGG-3') and 1041R (5'GGCCATGCACCWCCTCTC-3'). The amplification products were purified and sequenced using a Wizard PCR Preps DNA Purification System kit (Promega), a CEQ Dye Terminator Cycle Sequencing kit and CEQ 2000 XL automatic DNA sequencer (Beckman Coulter), according to the manufacturers' instructions. An almost-complete sequence ( $1434 \mathrm{bp})$ of the 16S rRNA gene was obtained from strain $\mathrm{M} 2^{\mathrm{T}}$. Phylogenetic $16 \mathrm{~S}$ rRNA gene sequence analyses were performed with the neighbour-joining method (Saitou \& Nei, 1987) using the maximumcomposite-likelihood model for estimating evolutionary distances between DNA sequences (Tamura et al., 2004). Bootstrap values based on 1000 replicates were estimated using MEGA4 (Tamura et al., 2007). The 16S rRNA gene sequence tree (Fig. 2) clearly demonstrated that strain $\mathrm{M}^{\mathrm{T}}$ was a member of the family Methanobacteriaceae in the order Methanobacteriales and that its closest phylogenetic relatives were $M$. bryantii DSM $863^{\mathrm{T}}$ (99\% $16 \mathrm{~S}$ rRNA gene sequence similarity) and $M$. veterum $\mathrm{MK}^{\mathrm{T}}(99 \%)$.

On the basis of the 16S rRNA gene sequence analysis and comparisons of characteristics of non-motile, rod-shaped, methanogenic strains that utilize $\mathrm{H}_{2} / \mathrm{CO}_{2}$ for growth and methane generation, strain $\mathrm{M}^{\mathrm{T}}$ was related to the genus Methanobacterium (Boone \& Whitman, 1988; Bonin \& Boone, 2006). Strain $\mathrm{M} 2^{\mathrm{T}}$ differed from M. bryantii VKM $\mathrm{B}-1629^{\mathrm{T}}$ and $M$. veterum $\mathrm{MK}^{\mathrm{T}}$ by its ability to utilize formate as a sole carbon and energy source and other phenotypic differences (Table 1) and exhibited low DNADNA relatedness with its closest phylogenetic relatives.

Table 1. Differential characteristics of strain $M 2^{\top}$ and its closest phylogenetic relatives

Strains: 1 , Methanobacterium arcticum sp. nov. $\mathrm{M}^{\mathrm{T}} ; 2$, M. bryantii VKM B-1629 ${ }^{\mathrm{T}} ; 3$, M. veterum $\mathrm{MK} 4^{\mathrm{T}}$. Data were obtained in this study unless otherwise indicated. All strains grew with $\mathrm{H}_{2} / \mathrm{CO}_{2}$ and formed filaments.

\begin{tabular}{|c|c|c|c|}
\hline Characteristic & 1 & 2 & 3 \\
\hline Cell shape & Rods, cyst-like cells & Rods, clamps & $\operatorname{Rods}^{*}$ \\
\hline \multicolumn{4}{|l|}{ Cell dimensions $(\mu \mathrm{m})$} \\
\hline Width & $0.45-0.5$ & $0.5-0.6$ & $0.40-0.45^{*}$ \\
\hline Length & $3.0-6.0$ & $10-15$ & $2.0-8.0^{*}$ \\
\hline Substrate(s) & Formate & 2-Propanol, 2-butanol & Methylamine $/ \mathrm{H}_{2}$, methanol/ $\mathrm{H}_{2}$ \\
\hline Stimulatory factor(s) & None & Yeast extract, acetate & Acetate \\
\hline \multicolumn{4}{|l|}{ Temperature for growth $\left({ }^{\circ} \mathrm{C}\right)$} \\
\hline Range & $15-45$ & $10-50$ & $10-45$ \\
\hline Optimum & 37 & 37 & 28 \\
\hline \multicolumn{4}{|l|}{$\mathrm{pH}$ for growth } \\
\hline Range & $5.5-8.5$ & $5.8-8.8$ & $5.2-9.4^{*}$ \\
\hline Optimum & $6.8-7.2$ & $6.9-7.0$ & $7.0-7.2^{*}$ \\
\hline \multicolumn{4}{|c|}{$\mathrm{NaCl}$ concentration for growth (M) } \\
\hline Range & $0-0.3$ & $0-0.3$ & $0-0.3^{*}$ \\
\hline Optimum & 0.1 & $0-0.3$ & $0.05^{\star}$ \\
\hline DNA $\mathrm{G}+\mathrm{C}$ content $(\mathrm{mol} \%)$ & 38.1 & 35.2 & $33.8^{*}$ \\
\hline
\end{tabular}

${ }^{\star}$ Data from Krivushin et al. (2010). 
Therefore, strain $\mathrm{M} 2^{\mathrm{T}}$ represents a novel species of the genus Methanobacterium, for which we propose the name Methanobacterium arcticum sp. nov.

\section{Description of Methanobacterium arcticum sp. nov.}

Methanobacterium arcticum (arc'ti.cum. L. neut. adj. arcticum northern, arctic, from the Arctic, referring to the isolation of the type strain from Arctic permafrost).

Cells are Gram-negative, non-motile, non-spore-forming, slightly curved rods, $0.45-0.50 \mu \mathrm{m}$ wide and $3.0-6.0 \mu \mathrm{m}$ long. Often forms filaments and cyst-like coccoid cells. Strictly anaerobic. Chemoautotrophic. Optimal growth at $37{ }^{\circ} \mathrm{C}$; maximum temperature is $45^{\circ} \mathrm{C}$. Optimal growth at pH 6.8-7.2; no growth at pH 5.0 or 9.0. Utilizes $\mathrm{H}_{2} / \mathrm{CO}_{2}$ and formate for growth and methane generation, but not acetate, methanol, ethanol, 2-propanol, 2-butanol, methylamines, methanol $/ \mathrm{H}_{2}$ or methylamine $/ \mathrm{H}_{2}$. Growth is not stimulated by acetate. The DNA G $+\mathrm{C}$ content of the type strain is $38.1 \mathrm{~mol} \%$.

The type strain $\mathrm{M}^{\mathrm{T}}\left(=\right.$ DSM $19844^{\mathrm{T}}=$ VKM B- $\left.2371^{\mathrm{T}}\right)$ was isolated from Holocene permafrost sediments from the Kolyma lowland, Russia ( $\left.70^{\circ} 06^{\prime} \mathrm{N} 154^{\circ} 04^{\prime} \mathrm{E}\right)$.

\section{Acknowledgements}

We thank Dr Anatoliy Lysenko (Vinogradsky Institute of Microbiology, Moscow, Russia) for the determination of $G+C$ content and Dr Ekaterina Gavrish for help with restriction analysis. We are grateful to Dr Jean Euzéby for suggesting the species name. This work was supported by the RFBR (grant numbers 08-05-00268 and 08-04-01004).

\section{References}

Balch, W. E., Fox, G. E., Magrum, L. J. \& Wolfe, R. S. (1979). Methanogens: re-evalution of a unique biological group. Microbiol Rev 43, 260-296.

Bonin, A. S. \& Boone, D. R. (2006). The order Methanobacteriales. In The Prokaryotes, 3rd edn, vol. 3, pp. 231-243. Edited by M. Dworkin, S. Falkow, E. Rosenberg, K. H. Schleifer \& E. Stackebrandt. New York: Springer.

Boone, D. R. \& Whitman, W. B. (1988). Proposal of minimal standards for describing new taxa of methanogenic bacteria. Int J Syst Bacteriol 38, 212-219.

De Ley, J., Catloir, H. \& Reynarts, A. (1970). The quantitative measurement of DNA hybridization from renaturation rates. Eur J Biochem 12, 133-142.

El'-Registan, G. I., Muliukin, A. L., Nikolaev, I. A., Suzina, N. E., Gal'chenko, V. F. \& Duda, V. I. (2006). Adaptive functions of extracellular autoregulators of microorganisms. Mikrobiologiia 75, 446-456 (in Russian).

Huß, V. A. R., Festl, H. \& Schleifer, K. H. (1983). Studies on the spectrophotometric determination of DNA hybridization from renaturation rates. Syst Appl Microbiol 4, 184-192.

Konig, H. (1995). Isolation and analysis of cell walls from methanogenic Archaea. In Archaea: a Laboratory Manual, vol. 2, pp.
315-328. Edited by K. R. Sowers \& H. T. Schreier. Cold Spring Harbor, NY: Cold Spring Harbor Laboratory.

Kotelnikova, S., Macario, A. J. L. \& Pedersen, K. (1998). Methanobacterium subterraneum sp. nov., a new alkaliphilic, eurythemic and halotolerant methanogen isolated from deep granitic groundwater. Int J Syst Bacteriol 48, 357-367.

Krivushin, K. V., Shcherbakova, V. A., Petrovskaya, L. E. \& Rivkina, E. M. (2010). Methanobacterium veterum sp. nov., from ancient Siberian permafrost. Int J Syst Evol Microbiol 60, 455-459.

Marmur, J. (1961). A procedure for the isolation of deoxyribonucleic acid from microorganisms. J Mol Biol 3, 208-218.

Morita, R. Y. (1975). Psychrophilic bacteria. Bacteriol Rev 39, 144-167.

Powell, G. E. (1983). Interpreting gas kinetics of batch culture. Biotechnol Lett 5, 437-440.

Rivkina, E., Shcherbakova, V., Laurinavichuis, K., Petrovskaya, L., Krivushin, K., Kraev, G., Pecheritsina, S. \& Gilichinsky, D. (2007). Biogeochemistry of methane and methanogenic archaea in permafrost. FEMS Microbiol Ecol 61, 1-15.

Saitou, N. \& Nei, M. (1987). The neighbor-joining method: a new method for reconstructing phylogenetic trees. Mol Biol Evol 4, 406425.

Sambrook, J., Fritsch, E. F. \& Maniatis, T. (1989). Molecular Cloning: a Laboratory Manual, 2nd edn. Cold Spring Harbor, NY: Cold Spring Harbor Laboratory.

Shcherbakova, V. A., Chyvilskya, N. A., Rivkina, E. M., Pecheritsyna, S. A., Laurinavichius, K. S., Suzina, N. E., Osipov, G. A., Lysenko, A. M., Gilichinsky, D. A. \& Akimenko, V. K. (2005). Novel psychrophilic anaerobic spore-forming bacterium from the overcooled water brine in permafrost: description Clostridium algoriphilum sp. nov. Extremophiles 9, 239-246.

Shi, T., Reeves, R. H., Gilichinsky, D. A. \& Friedmann, E. I. (1997). Characterization of viable bacteria from Siberian permafrost by $16 \mathrm{~S}$ rDNA sequencing. Microb Ecol 33, 169-179.

Shlimon, A. G., Friedrich, M. W., Niemann, H., Ramsing, N. B. \& Finster, K. (2004). Methanobacterium aarhusense sp. nov., a novel methanogen isolated from a marine sediment (Aarhus Bay, Denmark). Int J Syst Evol Microbiol 54, 759-763.

Smibert, R. \& Krieg, N. R. (1994). Phenotypic characterization. In Methods for General and Molecular Bacteriology, pp. 607-652. Edited by P. Gerhardt, R. G. E. Murray, W. A. Wood \& N. R. Krieg. Washington, DC: American Society for Microbiology.

Sowers, K. R. \& Noll, K. M. (1995). Techniques for anaerobic growth. In Archaea: a Laboratory Manual, vol. 2, pp. 15-48. Edited by K. R. Sowers \& H. T. Schreier. Cold Spring Harbor, NY: Cold Spring Harbor Laboratory.

Suzina, N. E., Mulyukin, A. L., Dmitriev, V. V., Nikolaev, Y. A., Shorokhova, A.P., Bobkova, Y. S., Barinova, E. S., Plakunov, V. K., El-Registan, G. I. \& Duda, V. I. (2006). The structural bases of longterm anabiosis in non-spore-forming bacteria. Adv Space Res 38, 1209-1219.

Tamura, K., Nei, M. \& Kumar, S. (2004). Prospects for inferring very large phylogenies by using the neighbor-joining method. Proc Natl Acad Sci U S A 101, 11030-11035.

Tamura, K., Dudley, J., Nei, M. \& Kumar, S. (2007). MEGA4: molecular evolutionary genetics analysis (MEGA) software version 4.0. Mol Biol Evol 24, 1596-1599.

Whitman, W. B., Bowen, T. L. \& Boone, D. R. (2006). The methanogenic bacteria. In The Prokaryotes, 3rd edn, vol. 3, pp. 165207. Edited by M. Dworkin, S. Falkow, E. Rosenberg, K. H. Schleifer \& E. Stackebrandt. New York: Springer. 